\title{
High Resolution Manometry - A Mandatory Examination in the Pre and Postoperative Assessment of Patients with Achalasia
}

\section{Anca Dimitriu and Cristian Gheorghe}

Center for Digestive Diseases and Liver Transplantations, Fundeni Clinical Institute, Bucharest, Romania

Corresponding author:

Anca Dimitriu, MD

Center for Digestive Diseases

and Liver Transplantations

Fundeni Clinical Institute, Bucharest

Romania

E-mail: borcaanca@yahoo.com

\section{Rezumat}

Manometria esofagiană cu rezoluție înaltă - o investigație importantă în evaluarea pre și postoperatorie a pacienților cu acalazie

Manometria esofagiană cu rezoluție înaltă este actual investigația gold-standard în diagnosticul acalaziei şi a bolilor esofagiene funcționale. Această examinare este întotdeauna precedată de endoscopia digestivă superioară, care are scopul de a face diagnosticul diferențial al acalaziei cu pseudoacalazia (formațiuni tumorale de fornix gastric/esofag distal). La momentul actual, nu există tratament curativ pentru acalazie. Însă, cele 3 subtipuri de acalazie (conform clasificării Chicago) au răspuns diferit în ceea ce priveşte eficacitatea în tratamentului ales. Astfel, comparativ cu tipurile I şi III, tipul II de acalazie are cel mai bun răspuns la intervențiile terapeutice invazive (dilatare pneumatică sau cardiomiotomie Heller). În schimb, în tipul III cardiomiotomia Heller este de ales ca prima abordare terapeutică. Miotomia endoscopică perorală (POEM) este o tehnică relativ recentă, care necesită însă studii pe termen lung în ceea ce priveşte siguranța şi eficacitatea. Articolul prezent îşi propune să prezinte variantele actuale de tratament ale acalaziei, comparându-le pe baza eficacității şi siguranței pe termen scurt şi lung, subliniind de asemenea rolul manometriei cu rezoluție înaltă în diagnosticul, alegerea metodei terapeutice şi prognosticul acestor pacienți.

Cuvinte cheie: acalazie, maonometrie esofagiană cu rezoluție înaltă, dilatare pneumatică, miotomie Heller 


\begin{abstract}
High resolution manometry (HRM) is currently the gold standard for the diagnosis of achalasia and other functional esophageal disorders. All patients accusing dysphagia should be endoscopically evaluated prior to manometric investigations in order to rule out pseudoachalasia. The Chicago HRM classification has led to a subclassification of three manometric types of achalasia that seem to have different results to treatment. None of the actual achalasia treatment options are curative. Type II achalasia patients respond best to all treatment options compared to those with types I and III. Pneumatic dilation (PD) or Heller miotomy (LHM) can be both chosen as initial therapy in type I and II as they have good outcome, while type III achalasia patients respond better to LHM as a first therapeutic option. Peroral endoscopic myotomy (POEM) is a promising new technique but long-term follow-up studies for its safety and efficacy must be performed. This article reviews the current therapeutic options in achalasia and other functional esophageal disorders, based on the differences in safety and efficacy between approaches, highlighting the impact of HRM to predict the outcome but also the role of the techinque in guiding antireflux surgery.
\end{abstract}

Key words: achalasia, high-resolution manometry, pneumatic baloon dilatation, Heller's myotomy

\section{Introduction}

High-resolution manometry (HRM) was introduced in 1990 by Ray Clouse and Geoff Hebbard and is currently the gold standard for assessing esophageal motility and diagnosis of motility disorders $(1,2)$. The technique has gradually replaced conventional manometry, having over the following improvements: increased number of pressure sensors with shorter spacing between $(1 \mathrm{~cm})$ allowing a complete depiction of esophageal motor function from upper esophageal sphincter (UES) to lower esophageal sphincter (LES); the visual display simplifies the correct positioning of the catheter (3); significantly shorter procedure time, faster learning curve, more objective interpretation with better interobserver and intraobserver agreement (4-7)

For a correct measurement, a baseline gastric pressure must be recorded. In order to do this, EGJ must be passed and the distal tip of the catheter positioned in the gastric cavity before starting the study. Esogastric junction (EGJ) is easier to locate with HRM, which also permits to verify if the catheter entered the stomach based on the variation of pressure in thorax and abdomen during respiration (8).

HRM has an important role in diagnosing and classification of esophageal motility disorders once the organic diseases have been excluded on endoscopy (benign or malignant stenosis, eospinophilic esophagitis, etc). Combining the pattern of esophageal peristaltis with the behaviour of LES during each swallow, the Chicago classification v3.0 defines achalasia, aperistaltis, distal esophageal spasm and jackhammer esophagus as major disorders (can never be seen in normal individuals), while ineffective motility (IEM) and fragmented peristaltis are considered minor disorders, (abnormal patterns, which can be found in asymptomatic individuals) (9).

The precise identification of EGJ and its proximal/distal limits with HRM explains also the role of the techinque prior to $\mathrm{pH}$ monitoring, where a correct positioning of the ph-sensor in the esophagus ( $5 \mathrm{~cm}$ proximal to LES) is mandatory (10).

\section{Achalasia}

\section{Pathogenesis and epidemiology}

Achalasia is a rare primary esophageal motor disorder characterized by the absence of peristalsis and impaired relaxation of LES, resulting in alteration of bolus transport and food stasis in the esophagus $(11,12)$. 
The etiology is unknown, although autoimmune, viral immune, or neurodegenerative causes may be considered triggers of the disease. The end result is a degeneration of ganglion cells in the myenteric plexus of the esophageal body and the LES, creating an imbalance between the excitatory and inhibitory neurons (11-14).

Achalasia has no racial or gender predilection, the peak incidence being between 30 and 60 years (14).

\section{Clinical Presentation}

Patients usually presen with one or more of the following symptoms: long history of dysphagia for both solids and liquids, regurgitation of saliva or undigested food, chest pain, weight loss, heartburn or nocturnal cough (14). Heartburn and nocturnal cough can initially lead to a diagnosis of gastroesophageal reflux disease (GERD). Chest pain is the most refractory and difficult to treat symptom, as opposed to dysphagia and regurgitation which usually respond to treatment (15). The Eckardt score grades the 4 most frequent symptoms (dysphagia, chest pain, regurgitation,weight loss) based on their frequence of occurence (each meal, daily,weekly or never). It is used in clinical practice for the evaluation of symptoms' severity at baseline and also for establishing the efficacy of achalasia treatment. Before HRM era, a symptom score of $0-1$ corresponded to clinical stage 0 , a score of 2-3 to stage I, a score of 4-6 to stage II, and a score $>6$ to stage III. Stages 0 and I indicated remission of the diseass, while stages II and III represented failure of treatment $(15,16)$. The role of Eckhardt score in the evaluation of treatment efficacy significantly decreased during the last years, being replaced by more objective HR manometric parameters $(14,15)$.

\section{Diagnosis}

The first diagnostic step is to exclude a benign or malignant obstruction using endoscopy, with careful examination of the EGJ and gastric cardia on retroflexed view, as they can mimic achalasia both clinically and manometricall (17-
19). In patients with dysphagia, esophageal biopsies are generally recommended in order to rule out eosinophilic esophagitis. However, it is not uncommon to find an increased number of eosinophils in patients with achalasia secondary to inflammatory process related to stasis $(20,21)$. More than that, motility disorders may be found in up to $25 \%$ patients with eosinophilic esophagitis, ineffective esophageal motility being the most common finding (22). In achalasia, endoscopy may reveal a dilated esophagus, with retained food or saliva or/and a rosette appearance of the EGJ with mild resistance to scope passage into the stomach. Also, due to stasis, a large number of patients with achalasia also associate esophageal candidiasis, an entity that is very important to detect and treat before any therapeutic intervention for achalasia is applied, as it can be associated with a higher risk of complication if left untreated (18).

The classical appearance of achalasia on Barium studies is with "bird beak" aspect of EGJ, varying degrees of esophageal dilation up to sigmoid esophagus, an air-fluid level or absence of the gastric air bubble (23).

The assessment of esophageal motor function is essential in the diagnosis of achalasia. Barium esophagram and endoscopy are only complementary tests, and in early stages, these may be completely normal $(18,23)$.

The manometric findings of aperistalsis and incomplete LES relaxation strongly sustains a diagnosis of achalasia. The presence of only one of these findings is rare in achalasia, but have also been described, mostly in pre-HRM era (24-27). Aperistalsis can present with different pressure patterns, such as a quiescent esophageal body (type I), isobaric pan-esophageal pressurization (type II), and spastic contractions (type III) (26).

\section{Treatment}

Because the pathogenesis is incompletely understood, all the available therapeutic options have only a palliative effect, and not a curative intent in achalasia. The common purpose is to abolish the EGJ pressure in order to improve esophageal emptying, relieve 
the primary symptoms of dysphagia and regurgitation, and prevent the development of megaesophagus.

The current standard of care include endos-copic pneumatic dilation or myotomy across LES, which can be performed either endoscopically (POEM) or surgically (laparoscopic Heller myotomy (LHM). None of these interventions can significantly improve esophageal peristaltis. Moreover, LES hypertonicity returns overtime, requiring repeated procedures (12).

\section{Pharmacological Approach}

Pharmacological approach with nitrates or calcium channel blockers is considered the least effective option and has a minor role in the treatment of esophageal achalasia. The drug tachifilaxia develops rapidly, so the clinical response is not only incomplete but also short in duration. Other limiting factor in their use is given by the associated side-effects, such as headache, hypotension and leg edema. Thus, pharmacological treatment is reserved for patients who are not able or refuse to undergo other more invasive therapies and for those in whom Botox has failed (12).

\section{Endoscopic Injection of Botox}

Endoscopic injection of Botox into the LES has an initial succes rate in controlling symptoms of $75 \%$, associated adverse effects are rare and in general minor in severity (reflux symptoms, abdominal pain). However, the action only persist for 3 to 4 months, half of patients relapse and need reintervention at 6-24 months after the first injection, thus limiting the use in clinical practice. There is some evidence that repeated injections could affect the subsequent surgical miotomy, thus the use of Botox should be reserved to elderly patients or patients with associated pathology who have contraindications for endoscopic dilation or miotomy (28-30).

In Romania the injection of Botox is not reimbursed so the procedure has also the disadvantage of being highly expensive.

Patients with type II achalasia proved a prolongued clincal effect of Botox injection, compared with type I and III, but this may be a characteristic of this type of achalasia, as type II patients have the best response rates at all therapies (Botox, pneumatic dilation, miotomy). When comparing the initial symptomatic relief after Botox injection with the one after PD or LHM, 5 randomized studies have shown a similar effect, but a fastter loss of response in patients treated with Botox (30-33).

\section{Pneumatic Dilation}

Pneumatic dilation (PD) is an effective nonsurgical treatment for achalasia (34). The procedure is performed under sedation and fluoroscopic guidance. The balloon is endoscopically placed across the LES , then gradually inflated to 6-12 psi with the aim of maintaining this pressure for approximately 15-60 sec (35). The balloons are available in three diameters: 30,35 and $40 \mathrm{~mm}$. The initial approach uses a $30 \mathrm{~mm}$ balloon, subsequent dilations being scheduled on the basis of clinical symptom relief (Eckardt symptom score) or manometric parameters improvement (IRP- LES) (36-40). Repeated dilations with a greater ballon diameter should be performed in patients who maintained a symptom-score of $>3$, if IRP LES pressure decreased less than $50 \%$ of the baseline pre-PD value, or if the IRP LES pressure is greater $10 \mathrm{mmHg}$ at first follow up visit. The timing of the first follow up visit after PD is variable in the literature, being usually scheduled after 4-12 weeks. A 3-mo posttreatment LES pressure above $10 \mathrm{mmHg}$ was associated with $5^{-}$and 10-year symptom recurrence rates of $25 \%$ and $33 \%$, respectively (36).

Gheorghe $\mathrm{C}$ et al also showed that patients with elevated LES pressure, short LES and wide esophagus should be considered as primary surgical candidates. To note, the study evaluated only the short time (3 months) response rate, so further studies are needed in romanian patients with achalasia (37).

We may consider that a high initial LES pressure $(>15-30 \mathrm{mmHg})$ or a reduction of LES pressure less than $50 \%$ after the first dilation are predictors of poor outcomes for PD (38-40).

During a prolonged observation period (median, 13.8 years) in a prospective follow-up 
investigation study conducted by Eckardt et a (41), only $40 \%$ of patients treated with a single round of $\mathrm{PD}$ remained in remission at 5 years. Many studies suggest and reccomend to use a graded dilator approach, given the good to excellent relief of symptoms in 50-93\% of the treated patients $(42-44)$.

Using only subjective symptomatic scoring assessment to determine clinical remission is prone to errors in considering treatment insuccess. It is suggested strongly that manometry to be performed routinely before and after PD, and to use the registered parameters in guiding future therapeutic approach (44).

Predictors of the best clinical outcomes after PD include: age older than 40 years, women, LES pressure after dilatation $<10 \mathrm{mmHg}$ and type II pattern by HRM $(14,23,45,46)$.

One third of patients experience complications, most of them minor (chest pain, bleeding, aspiration pneumonia, fever, esophageal hematoma, mucosal tear) (47). Esophageal perforation is the most serious one, occuring with an overall median rate of $1.9 \%$ in experienced hands. The rate is higher in elderly, when the first PD baloon diameter was $35 \mathrm{~mm}$ instead a $30 \mathrm{~mm}$ (47). The inability to keep the balloon in an appropriate position also seems to be a potential risk factor (47).

GERD may occur after PD in a range of $15^{-}$ $35 \%$ of the patients and PPI therapy can improve their reflux-related symptoms (48).

Overall, PD is the most cost-effective treatment for achalasia over a 5-10-year follow-up period $(49,50)$.

Switch to Heller myotomoy is indicated if 3 consecutive pneumatic dilations have failed to induce a clinical and manometric remission (38).

\section{Heller Myotomy}

The surgical procedure most widely used to treat achalasia is Heller myotomy, performed either thoracoscopic, laparoscopic or robotic. For an effective symptom relief, SAGES recommends that the length of the esophageal myotomy should be at least $4 \mathrm{~cm}$ on the esophagus and 1-2 $\mathrm{cm}$ on the stomach. The association of a fundoplication significantly reduced the development of GERD, which was the most frequently encountered side effect of the procedure $(51,52)$. A recent meta-analysis by Campos et al proved that the symptoms of GERD improved significantly more after a laparoscopic (3086 patients) compared with the thoracoscopic approach (211 patients) $(89.3 \%$ vs. $77.6, \mathrm{P}=0.048)$ and when an antireflux procedure was added, without affecting the therapeutic success $(31.5 \%$ vs. $8.8 \%)(53)$. A recent multicenter randomized controlled trial comparing anterior Dor and posterior Toupet approach suggested that both provide similar control of reflux after LHM $(57,58)$. In view of the absence of peristalsis in achalasia, partial fundoplication is preferred, as postoperative dysphagia is significantly higher after a Nissen fundoplication than after partial anterior approach (56). LHM combined with a partial fundoplication is considered a safe operation with a low mortality rate (57). The most common complication of LHM is perforation (6.3\%) during the myotomy, usually repaired onsite, without clinical consequences (61).

Clinical success rates are very high, with a mean success rate of $89 \%$ at a follow up of 35 months (51-53).

The patients who will mostly benefit from LHM are young men (<40 years), with a LES pressure greater than $30 \mathrm{mmHg}$ and a straight, untortuous esophagus $(61,62)$.

Patients with type II HRM achalasia pattern have the best outcome after LHM (63). There is no difference in clinical success rates between PD and LHM for patients with types I and type II achalasia, but the type III pattern responds better to surgery than to PD, probably because of the more extensive proximal disruption of the esophageal muscle (63).

As with other therapeutic options available, the rate drops to $65-85 \%$ after 5 years (64).

Prior endoscopic treatment for achalasia may be associated with higher myotomy morbidity, but the literature is inconclusive. Several studies have reported higher intraoperative esophageal perforation rates during esophagomyotomy after prior endoscopic intervention (65-67).

For example, Portale et al reported that patients who previously underwent Botox 
injection and PD had less successful outcome in LHM and increased risk of mucosal perforation, probably due to fibrosis at the GE junction $(64,65)$.

In contrast, other authors reported no differences in complications rate or the degree of surgical difficulty, but similar outcomes after myotomy in patients with prior failed PD or Botulinum toxin injection $(66,67)$. In fact, surgical complication rates are thought to be more dependent on surgeon experience and the incidence of previous esophageal surgery than on prior botulinum toxin injection or prior pneumatic dilatation (68). In conclusion, LHM can be safley and efficiently performed after PD or Botox injections, but a careful approach by an experienced team is advisable.

In contrast, other studies found no association between preoperative endoscopic treatment and intraoperative perforations (58), and some authors have reported no difference in the degree of surgical difficulty (62). In addition, several authors have also reported similar patient outcomes after myotomy even after prior failed pneumatic dilation or Botulinum toxin injections Surgery after botulinum toxin injections has been suggested to be more difficult because of a marked fibrotic reaction that can develop at the gastroesophageal junction that obliterates surgical planes (62-65). Nevertheless, some authors have reported similar outcomes in this situation to those of a primary procedure (66-68).

Recurrences after LHM can be treated with Botulinum toxin treatment with equal safety and efficiency as before myotomy. Most experts recommend avoidance of $\mathrm{PD}$ after failed myotomy due to increased perforation rate. Repeated myotomy may be superior to endoscopic treatment if performed by experienced surgeons but esophagectomy should also be considered in appropriately selected patients after myotomy failure $(66,67)$.

In end-stage achalasia, characterized by the presence of a massively dilated and tortuous oesophagus (ussualy $>6 \mathrm{~cm}$ ), esophageal resection may be the unique remaining option. Evaney et al. reported one of the largest series of 93 patients who underwent oesophagectomy for end-stage achalasia. They stated that esophagectomy is the only therapeutic intervention to be performed, as the tortuosity will interfere with the esophageal emptying even after adequate myotomy (69).

Both PD and LHM are effective treatment options for achalasia. Some studies showed a superiority of the surgery procedure in controlling symptoms and in symtopm-free duration, (68). In line with these data, a romanian study retrospectivally compared the two methods in 112 patients and LHM was found to be superior regarding efficacy compared to PD both in the short- (1 year) (92\% vs $80 \%)$ and long-term (5 years) ( $80 \%$ vs $64 \%)$. However, the limitations of these studies are either a low number of patients included, a short follow up period, or only subjective clinical scoring systems in considering treatment efficacy $(68,69)$.

In 2011 Boeckstaens et al reported the results of the European Achalasia Trial, The first multicenter randomized controlled trial comparing PD with LHM combined with Dor fundoplication. Therapeutic success was defined as a reduction in the Eckardt symptom score below 4 . The report proves similar and excellent outcomes over a 2-year follow-up with both PD and LHM in a study involving 201 achalasia patients $(86 \%$ vs $90 \%)$ ).Although longer follow up is required, the authors concluded that LHM does not achieve superior rates of therapeutic success compared with PD as primary treatment for achalasia, at least after a mean follow up of 43 months, and, therefore, either one can be recommended as an initial therapy (15).

The advantage of LHM over PD is given by the fact that is a single procedure with similar, or slightly longer relief on symptoms. The advantages of PD over LHM are given by the minimal pain associated, mild if any GERD, acceptability any age group and even during pregnancy, performance as an outpatient procedure and lower cost (61-63).

\section{Peroral Endoscopic Myotomy}

Peroral endoscopic myotomy (POEM) is a relatively new technique that combines the endoscopic approach with principles of natural 
orifice transluminal endoscopic surgery to perform a myotomy (70). The existing studies reported a high success rate (85-100\%) even after several previous PD, but a high risk to develop GERD as no antireflux procedure is included (46\%). Marano et al compared POEM with LHM in terms of efficacy and safety on 486 patients. The results showed no differences between POEM and LHM in reduction in Eckardt score, operative time, postoperative pain scores, analgesic requirements or complications. The length of hospital stay was higher in POEM group, and the GE reflux rate was lower in the LHM group. POEM represents a safe and efficacy procedure comparable to the safety profile of LHM for achalasia at a shortterm follow-up (71).

Sanaka et all compared the 3 available therapeutic options (PD, POEM, LHM) in 200 patients, using also manometric parameters for establishing the efficacy of each option, beside radiological markers and clinical subjective scores. At 2 mo post-treatment, there was significant improvement in basal LES pressure and LES-IRP in both LHM $(40.5 \mathrm{mmHg}$ vs 14.5 $\mathrm{mmHg}$ and $24 \mathrm{mmHg}$ vs $7.1 \mathrm{mmHg}$ respectively, $\mathrm{P}<0.001)$ and POEM groups $(38.7 \mathrm{mmHg}$ vs $11.4 \mathrm{mmHg}$ and $23.6 \mathrm{mmHg}$ vs $6.6 \mathrm{mmHg}$ respectively, $\mathrm{P}<0.001)$. Moreover, LES-IRP at 2 mo decreased to less than $10 \mathrm{mmHg}$ in 66/92 patients (71.7\%) in LHM group, 19/26 patients (73.1\%) in POEM group. PD was compared with POEM and LHM only based on the radiological markers at Barium Swallow. At 2 mo posttreatment, barium column height, width and volume remaining at 1 and 5 min improved significantly in all three treatment groups $(P=0.01$ to $P<0.001)$ except the column height at 1 min in PD group $(\mathrm{P}=0.11)$ The authors concluded that POEM, PD and LHM were all effective in improving esophageal function in achalasia at short-term, with no difference in efficacy between the three treatments (72).

\section{Other Esophgaeal Functional Disorders}

As for the other functional disorders in the Chicago classification, Botox injection and POEM have some arguments of being efficient and safe in patients with EGJ outflow obstruction, distal esophageal spasm or jackhammer esophagus but studies are limited and inconclusive. Treatment options for absent peristalsis are limited, as No pharmacological intervention can restore esophageal peristalsis. Fundoplication or gastric bypass surgery is absolutely contraindicated in the patients and should be avoided (8).

\section{HRM and ph-analyisis Role in Guiding Antireflux Surgery}

HRM has also an important role in evaluating esophageal peristaltis prior to antireflux surgery, guiding the type of fundoplication to be performed in order to minimize the rate of dysphagia appearance. A partial fundoplication is indicated in cases of ineffective esophageal motility, an entity which is frequently associated with GERD.

Prior to antireflux surgery, esophageal $\mathrm{pH}^{-}$ metry is highly recommended in all patients, and it is mandatory in those without obvious erosive-ulcerative reflux esophagitis. The identification and classification of patients with nonerosive reflux disease, hypersensitive esophagus or functional heartburn based on ph-analysis is helpful in deciding whether or not they would actually have a significant benefit after antireflux surgery. Thus, an antireflux surgery will have no benefit in patients with normal reflux episodes, even if their symptoms are associated (Hypersensitive esophagus) or not (Functional heartburn) with reflux episodes, but would clearly resolve symptoms in individuals with frequent symptoms, associated with a high number of reflux episodes and negative endoscopy (10).

\section{Conclusion}

In conclusion, HRM is a very useful tool not only in diagnosing patients with functional disorders of the esophagus, but also in guiding therapy and quantifying the response to different treatment options. The identification of the three subtypes of achalasia with the technique has prognostic implication and may also guide 
the first treatment option to be chosen. HRM combined with $\mathrm{pH} 24 \mathrm{~h}$-analysis and multichannel Impedance has a role in selecting patients for antireflux surgery and guides the type of intervention based on their peristaltic particularities.

\section{References}

1. Hebbard, GS, Feinle, C, and Kunz, P. Technical aspects of highresolution perfusion manometry - an underwater zero improves accuracy of measurement of catheter offset and transducer drift. Gastroenterology. 1997;112:A745.

2. Roman S, Huot L, Zerbib F, Bruley des Varannes S, Gourcerol G, Coffin $B$, et al. High-resolution manometry improves the diagnosis of esophageal motility disorders in patients with dysphagia: a randomized multicenter study. Am J Gastroenterol. 2016;111(3): 372-380. doi: 10.1038/ajg.2016.1

3. Clouse, RE, Parks, T, Haroian, L, and Zakko, SF. Development and clinical validation of a solid-state high-resolution pressure measurement system for simplified and consistent esophageal manometry. Am J Gastroenterol. 2003;98:S32-S33.

4. Carlson DA, Ravi K, Kahrilas PJ, Gyawali CP, Bredenoord AJ, Castell DO, et al. Diagnosis of esophageal motility disorders: esophageal pressure topography vs. conventional line tracing. Am J Gastroenterol. 2015;110(7):967-977. doi: 10.1038/ajg.2015.159.

5. Soudagar AS, Sayuk GS, Gyawali CP. Learners favour high resolution oesophageal manometry with better diagnostic accuracy over conventional line tracings. Gut. 2012;61(6):798-803. doi: 10.1136/ gutjnl-2011-301145.

6. Fox MR, Pandolfino JE, Sweis R, Sauter M, Abreu Y, Abreu AT, et al Interobserver agreement for diagnostic classification of esophageal motility disorders defined in high-resolution manometry. Dis Esophagus. 2015;28(8):711-9. doi: 10.1111/dote.12278. Epub 2014 Sep 3.

7. Bogte, A, Bredenoord, AJ, Oors, J, Siersema, PD, and Smout, AJ. Reproducibility of esophageal high-resolution manometry. Neurogastroenterol Motil. 2011;23:e271-e276.

8. van Hoeij FB, Bredenoord AJ. Clinical Application of Esophageal Highresolution Manometry in the Diagnosis of Esophageal Motility Disorders. J Neurogastroenterol Motil 2016;22(1):6-13 doi: 10.5056/ jnm15177.

9. Kahrilas PJ, Bredenoord AJ, Fox M, Gyawali CP, Roman S, Smout AJ, et al. The Chicago classification of esophageal motility disorders, v3.0. Neurogastroenterol Motil. 2015;27(2):160-174. doi: $10.1111 / \mathrm{nmo} 0.12477$

10. Savarino E, Bredenoord AJ, Fox M, Pandolfino JE, Roman S, Gyawali CP. Advances in the physiological assessment and diagnosis of GERD. Nat Rev Gastroenterol Hepatol. 2017;14(11):665-676.

11. Pandolfino JE, Gawron AJ. Achalasia: a systematic review. JAMA. 2015;313(18):1841-52. doi: 10.1001/jam 1.

12. Vaezi MF, Pandolfino JE, Vela MF. ACG clinical guideline: diagnosis and management of achalasia. Am J Gastroenterol. 2013;108(8): 1238-49; quiz 1250. doi: 10.1038/ajg.2013.196. Epub 2013 Jul 23.

13. Francis DL, Katzka DA. Achalasia: update on the disease and its treatment. Gastroenterology. 2010;139(2):369-74. doi: 10.1053/ j.gastro.2010.06.024. Epub 2010 Jun 18.

14. Boeckxstaens GE, Zaninotto G, Richter JE. Achalasia. Lancet. 2014; 383(9911):83-93. doi: 10.1016/S0140-6736(13)60651-0. Epub 2013 Jul 17.

15. Boeckxstaens GE, Annese V, des Varannes SB, Chaussade $\mathrm{S}$, Costantini M, Cuttitta A, et al. Pneumatic dilation versus laparoscopic Heller's myotomy for idiopathic achalasia. N Engl J Med. 2011;364(19):1807-16. doi: 10.1056/ NEJMoa1010502.

16. Gockel I, Junginger T. The value of scoring achalasia: a comparison of current systems and the impact on treatment--the surgeon's viewpoint. Am Surg. 2007;73(4):327-31.

17. Tucker HJ, Snape WJ Jr, Cohen S. Achalasia secondary to carcinoma: manometric and clinical features. Ann Intern Med. 1978;89(3):315-8.

18. Dodds WJ, Stewart ET, Kishk SM, Kahrilas PJ, Hogan WJ. Radiologic amyl nitrite test for distinguishing pseudoachalasia from idiopathic achalasia. AJR Am J Roentgenol. 1986;146(1):21-3.

19. Kahrilas PJ, Kishk SM, Helm JF, Dodds WJ, Harig JM, Hogan WJ. Comparison of pseudoachalasia and achalasia. Am J Med. 1987; 82(3):439-46.

20. Goldblum JR, Whyte RI, Orringer MB, Appelman HD. Achalasia. Achalasia. A morphologic study of 42 resected specimens. Am J Surg Pathol. 1994; 18(4):327-37.

21. Rodrigo S, Abboud G, Oh D, DeMeester SR, Hagen J, Lipham J, et al. High intraepithelial eosinophil counts in esophageal squamous epithelium are not specific for eosinophilic esophagitis in adults. Am J Gastroenterol. 2008;103(2):435-42. doi: 10.1111/j.1572-0241. 2007.01594.x.

22. Monnerat MM, Lemme EM Eosinophilic esophagitis: manometric and pHmetric findings. Arq Gastroenterol. 2012;49(2):113-7.

23. Vaezi MF, Baker ME, Achkar E, Richter JE. Timed barium oesophagram: better predictor of long term success after pneumatic dilation in achalasia than symptom assessment. Gut. 2002;50(6):765-70.

24. Katz PO, Richter JE, Cowan R, Castell DO. Apparent complete lower esophageal sphincter relaxation in achalasia. Gastroenterology. 1986;90(4):978-83.

25. Hirano I, Tatum RP, Shi G, Sang Q, Joehl RJ, Kahrilas PJ. Manometric heterogeneity in patients with idiopathic achalasia. Gastroenterology. 2001; 120(4):789-98.

26. Morera C, Nurko S. Heterogeneity of lower esophageal sphincter function in children with achalasia. J Pediatr Gastroenterol Nutr. 2012;54(1):34-40. doi: 10.1097/MPG.0b013e3182293d8c.

27. Galey KM, Wilshire CL, Niebisch S, Jones CE, Raymond DP, Litle VR, et al. Atypical variants of classic achalasia are common and currently under-recognized: a study of prevalence and clinical features. J Am Coll Surg. 2011;213(1):155-61; discussion 162-3. doi: 10.1016/j.jamcollsurg.2011.02.008. Epub 2011 Mar 23.

28. Zaninotto G, Annese V, Costantini M, Del Genio A, Costantino M, Epifani $\mathrm{M}$, et al. Randomized controlled trial of botulinum toxin versus laparoscopic heller myotomy for esophageal achalasia. Ann Surg. 2004;239(3):364-70.

29. Smith CD, Stival A, Howell DL, Swafford V. Endoscopic therapy for achalasia before Heller myotomy results in worse outcomes than heller myotomy alone. Ann Surg. 2006;243(5):579-84; discussion 584-6.

30. Muehldorfer SM, Schneider TH, Hochberger J, Martus P, Hahn EG, EII C. Esophageal achalasia: intrasphincteric injection of botulinum toxin A versus balloon dilation. Endoscopy. 1999;31(7):517-21.

31. Ghoshal UC, Chaudhuri S, Pal BB, Dhar K, Ray G, Banerjee PK. Randomized controlled trial of intrasphincteric botulinum toxin $A$ injection versus balloon dilatation in treatment of achalasia cardia. Dis Esophagus. 2001;14(3-4):227-31.

32. Vaezi MF, Richter JE, Wilcox CM, Schroeder PL, Birgisson S, Slaughter RL, et al. Botulinum toxin versus pneumatic dilatation in the treatment of achalasia: a randomised trial. Gut. 1999;44(2): 231-9.

33. Mikaeli J, Fazel A, Montazeri G, Yaghoobi M, Malekzadeh R. Randomized controlled trial comparing botulinum toxin injection to pneumatic dilatation for the treatment of achalasia. Aliment Pharmacol Ther. 2001;15(9):1389-96.

34. Stefanidis D, Richardson W, Farrell TM, Kohn GP, Augenstein V, Fanelli RD, et al. SAGES guidelines for the surgical treatment of esophageal achalasia. Surg Endosc. 2012;26(2):296-311. doi: 10.1007/s00464-011-2017-2. Epub 2011 Nov 2.

35. Richter JE. Esophageal motility disorder achalasia. Curr Opin Otolaryngol Head Neck Surg. 2013;21(6):535-42. doi: 10.1097/ M00.0b013e3283658f4f.

36. Vela MF, Richter JE, Khandwala F, Blackstone EH, Wachsberger D, Baker ME, et al. The long-term efficacy of pneumatic dilatation and 
Heller myotomy for the treatment of achalasia. Clin Gastroenterol Hepatol. 2006;4(5):580-7.

37. Gheorghe C, Bancila I, Tutuian R, lacob R, Tomulescu V. Predictors of short term treatment outcome in patients with achalasia following endoscopic or surgical therapy. Hepatogastroenterology. 2012; 59(120):2503-7. doi: 10.5754/hge11284.

38. Kadakia SC, Wong RK. Graded pneumatic dilation using Rigiflex achalasia dilators in patients with primary esophageal achalasia. Am J Gastroenterol. 1993;88(1):34-8.

39. Eckardt VF, Aignherr C, Bernhard G. Predictors of outcome in patients with achalasia treated by pneumatic dilation. Gastroenterology. 1992;103(6):1732-8.

40. Rohof WO, Lei A, Boeckxstaens GE. Esophageal stasis on a timed barium esophagogram predicts recurrent symptoms in patients with long-standing achalasia. Am J Gastroenterol. 2013;108(1):4955. doi: 10.1038/ajg.2012.318. Epub 2012 Sep 25.

41. Eckardt VF, Gockel I, Bernhard G. Pneumatic dilation for achalasia: late results of a prospective follow up investigation. Gut. 2004; 53(5):629-33.

42. Vaezi MF, Richter JE. Current therapies for achalasia: comparison and efficacy. J Clin Gastroenterol. 1998;27(1):21-35.

43. Campos GM, Vittinghoff E, Rabl C, Takata M, Gadenstätter M, Lin F, et al. Endoscopic and surgical treatments for achalasia: a systematic review and meta-analysis. Ann Surg. 2009;249(1):45-57. doi: 10.1097/SLA.0b013e31818e43ab.

44. Swanstrom LL, Kurian A, Dunst CM, Sharata A, Bhayani N, Rieder E. Long-term outcomes of an endoscopic myotomy for achalasia: the POEM procedure. Ann Surg. 2012;256(4):659-67. doi: 10.1097/SLA.0b013e31826b5212.

45. Rohof WO, Salvador R, Annese V, Bruley des Varannes S, Chaussade $\mathrm{S}$, Costantini M, et al. Outcomes of treatment for achalasia depend on manometric subtype. Gastroenterology. 2013;144(4):718-25; quiz e134. doi: 10.1053/j.gastro.2012.12.027. Epub 2012 Dec 28.

46. Vantrappen G, Hellemans J, Deloof W, Valembois P, Vandenbroucke J. Treatment of achalasia with pneumatic dilatations. Gut. 1971; 12(4):268-75.

47. Katzka DA, Castell D0. Review article: an analysis of the efficacy, perforation rates and methods used in pneumatic dilation for achalasia. Aliment Pharmacol Ther. 2011;34(8):832-9. doi: 10.1111/ j.1365-2036.2011.04816.x. Epub 2011 Aug 17.

48. Richter JE. Update on the management of achalasia: balloons, surgery and drugs. Expert Rev Gastroenterol Hepatol. 2008;2(3): 435-45. doi: 10.1586/17474124.2.3.435

49. O'Connor JB, Singer ME, Imperiale TF, Vaezi MF, Richter JE. The cost-effectiveness of treatment strategies for achalasia. Dig Dis Sci. 2002;47(7):1516-25.

50. Karanicolas PJ, Smith SE, Inculet RI, Malthaner RA, Reynolds RP, Goeree R, et al. The cost of laparoscopic myotomy versus pneumatic dilatation for esophageal achalasia. Surg Endosc. 2007; 21(7):1198-206. Epub 2007 May 4.

51. Zaaijer JH. Cardiospasm in the aged. Ann Surg. 1923;77(5):615-7.

52. Dor J, Humbert P, Paoli JM, Miorclerc M, Aubert J. Treatment of reflux by the so-called modified Heller-Nissen technic. Presse Med. 1967;75(50):2563-5. French

53. Shimi S, Nathanson LK, Cuschieri A. Laparoscopic cardiomyotomy for achalasia. J R Coll Surg Edinb. 1991;36(3):152-4

54. Ali A, Pellegrini CA. Laparoscopic myotomy: technique and efficacy in treating achalasia. Gastrointest Endosc Clin N Am. 2001;11(2):34758 , vii.

55. Richards WO, Torquati A, Holzman MD, Khaitan L, Byrne D, Lutfi R, et al. Heller myotomy versus Heller myotomy with Dor fundoplication for achalasia: a prospective randomized double-blind clinical trial. Ann Surg. 2004;240(3):405-12; discussion 412-5.

56. Rebecchi F, Giaccone C, Farinella E, Campaci R, Morino M. Randomized controlled trial of laparoscopic Heller myotomy plus Dor fundoplication versus Nissen fundoplication for achalasia: long-term results. Ann Surg. 2008;248(6):1023-30. doi: 10.1097/ SLA.0b013e318190a776.

57. Rawlings A, Soper NJ, Oelschlager B, Swanstrom L, Matthews BD, Pellegrini C, et al. Laparoscopic Dor versus Toupet fundoplication following Heller myotomy for achalasia: results of a multicenter, prospective, randomized-controlled trial. Surg Endosc. 2012;26(1): 18-26. doi: 10.1007/s00464-011-1822-y. Epub 2011 Jul 26.

58. Mattioli S, Ruffato A, Lugaresi M, Pilotti V, Aramini B, D'Ovidio F. Long-term results of the Heller-Dor operation with intraoperative manometry for the treatment of esophageal achalasia. J Thorac Cardiovasc Surg. 2010;140(5):962-9. doi: 10.1016/j.jtcvs.2010.07. 053. Epub 2010 Sep 9.

59. Costantini M, Zaninotto G, Guirroli E, Rizzetto C, Portale G, Ruol A, et al. The laparoscopic Heller-Dor operation remains an effective treatment for esophageal achalasia at a minimum 6-year follow-up. Surg Endosc. 2005;19(3):345-51. Epub 2005 Jan 10.

60. Chen Z, Bessell JR, Chew A, Watson DI. Laparoscopic cardiomyotomy for achalasia: clinical outcomes beyond 5 years. J Gastrointest Surg. 2010;14(4):594-600. doi: 10.1007/s11605-010-1158-2. Epub 2010 Feb 5.

61. Torquati A, Richards WO, Holzman MD, Sharp KW. Laparoscopic myotomy for achalasia: predictors of successful outcome after 200 cases. Ann Surg. 2006;243(5):587-91; discussion 591-3.

62. Zaninotto G, Costantini M, Rizzetto C, Zanatta L, Guirroli E, Portale $\mathrm{G}$, et al. Four hundred laparoscopic myotomies for esophageal achalasia: a single centre experience. Ann Surg. 2008;248(6):98693. doi: 10.1097/SLA.0b013e3181907bdd.

63. Salvador R, Costantini M, Zaninotto G, Morbin T, Rizzetto C, Zanatta $L$, et al. The preoperative manometric pattern predicts the outcome of surgical treatment for esophageal achalasia. J Gastrointest Surg. 2010;14(11):1635-45. doi: 10.1007/s11605-010-1318-4

64. Patti MG, Feo CV, Arcerito M, De Pinto M, Tamburini A, Diener U, et al. Effects of previous treatment on results of laparoscopic Heller myotomy for achalasia. Dig Dis Sci. 1999;44(11):2270-6.

65. Portale G, Costantini M, Rizzetto C, Guirroli E, Ceolin M, Salvador $\mathrm{R}$, et al. Long-term outcome of laparoscopic Heller-Dor surgery for esophageal achalasia: possible detrimental role of previous endoscopic treatment. J Gastrointest Surg. 2005;9(9):1332-9.

66. Lynch KL, Pandolfino JE, Howden CW, Kahrilas PJ. Major complications of pneumatic dilation and Heller myotomy for achalasia: single-center experience and systematic review of the literature. Am J Gastroenterol. 2012;107(12):1817-25. doi: 10.1038/ajg.2012.332. Epub 2012 Oct 2.

67. Zaninotto G, Costantini M, Portale G, Battaglia G, Molena D, Carta A, et al. Etiology, diagnosis, and treatment of failures after laparoscopic Heller myotomy for achalasia. Ann Surg. 2002;235(2):186-92.

68. Kostic S, Kjellin A, Ruth M, Lönroth H, Johnsson E, Andersson M, et al. Pneumatic dilatation or laparoscopic cardiomyotomy in the management of newly diagnosed idiopathic achalasia. Results of a randomized controlled trial. World J Surg. 2007;31(3):470-8.

69. Bancila I, Gheorghe C. Heller myotomy and endoscopic balloon dilation may be equally effective in the shortand long-term, J Gastrointestin Liver Dis. 2017;26(3):321. doi: 10.15403/ jgld.2014. 1121.263.hll.

70. Inoue $\mathrm{H}$, Minami H, Kobayashi $\mathrm{Y}$, Sato $\mathrm{Y}$, Kaga M, Suzuki M, et al. Peroral endoscopic myotomy (POEM) for esophageal achalasia. Endoscopy. 2010;42(4):265-71. doi: 10.1055/s-0029-1244080. Epub 2010 Mar 30.

71. Marano L, Pallabazzer G, Solito B, Santi S, Pigazzi A, De Luca R, et al. Surgery or peroral esophageal myotomy for achalasia: a systematic review and meta-analysis. Medicine (Baltimore). 2016;95(10):e3001. doi: 10.1097/MD.0000000000003001.

72. Sanaka MR, Hayat U, Thota PN, Jegadeesan R, Ray M, Gabbard SL, et al. Efficacy of peroral endoscopic myotomy vs other achalasia treatments in improving esophageal function. World J Gastroenterol. 2016;22(20):4918-25. doi: 10.3748/wjg.v22.i20.4918. 